\title{
JUURNAL.RU
}

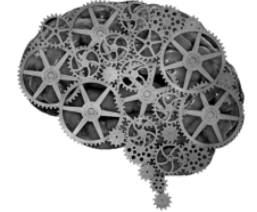

COMPANY GROUP "INTELLEKT"

\author{
Чеснаков С.П., Пичхиде С.Я. \\ СГТУ им. Ю.А. Гагарина \\ Саратов, Россия
}

doi: 10.18411/lj2016-3-43

\section{Усовершенствование конструкции эндопротеза тазобедренного сустава}

Эндопротезирование - это операция по замене поврежденного при болезни или травме сустава искусственным аналогом.

Известная конструкция эндопротеза тазобедренного сустава ревизионный состоит из ножки, дистальная часть которой выполнена в виде конуса, а проксимальная часть с медиальной стороны дугообразно изогнута и снабжена калькарной вставкой с опорным воротничком и шейкой. Эту конструкцию можно использовать только при отсутствии большого вертела, что сужает возможности ее использования при его сохранности.

В данной работе предлагаются следующие изменения конструкции прототипа эндопротеза тазобедренного сустава: 1) сделать более обтекаемую конструкцию ножки; 2) использовать гидроксиапатитовое покрытие ножки (титан марки ВТ-6 ГОСТ1987-91).

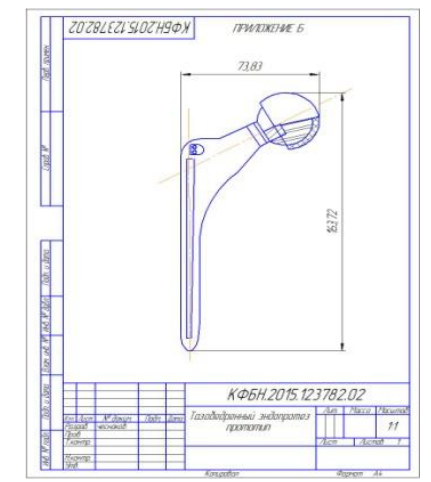

Рис.1. Прототип тазобедренного эндопротеза

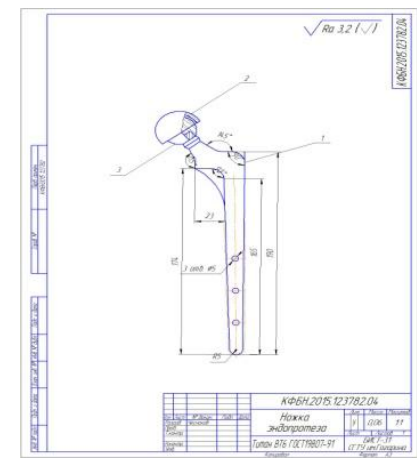

Рис.2. Тазобедренный эндопротез, где: 1ножка, 2- чаша, 3- головка 
Выводы: усовершенствована конструкция эндопротеза тазобедренного сустава, сделана более обтекаемая конструкция ножки, что делает конструкцию эндопротеза более прочной, тем самым увеличивая срок его службы.

\section{Литература:}

1. Патент РФ №2245688, А61F 2/32, БИМП 2005, №4.Эндопротоз тазобедренного сустава.

2. Патент РФ №2245689, А61F 2/32, БИПМ 2005, №4. Тазобедренный эндопротез.

3. Фокин В.А. Пары трения для тотальных эндопротезов тазобедренного сустава и проблема износа // Margo Anterior №4/2000. Бюл. AO/FSIF и МАТИС МЕДИКАЛ, с.1-4, с.5. 